\title{
CHANGES IN HARDWOOD FOREST UNDERSTORY PLANT COMMUNITIES IN RESPONSE TO EUROPEAN EARTHWORM INVASIONS
}

\author{
Cindy M. Hale, ${ }^{1}$ Lee E. Frelich, and Peter B. Reich \\ Department of Forest Resources, University of Minnesota, St. Paul, Minnesota 55108-6112 USA
}

\begin{abstract}
European earthworms are colonizing earthworm-free northern hardwood forests across North America. Leading edges of earthworm invasion provide an opportunity to investigate the response of understory plant communities to earthworm invasion and whether the species composition of the earthworm community influences that response. Four sugar maple-dominated forest sites with active earthworm invasions were identified in the Chippewa National Forest in north central Minnesota, USA. In each site, we established a 30 $\times 150 \mathrm{~m}$ sample grid that spanned a visible leading edge of earthworm invasion and sampled earthworm populations and understory vegetation over four years. Across leading edges of earthworm invasion, increasing total earthworm biomass was associated with decreasing diversity and abundance of herbaceous plants in two of four study sites, and the abundance and density of tree seedlings decreased in three of four study sites. Sample points with the most diverse earthworm species assemblage, independent of biomass, had the lowest plant diversity. Changes in understory plant community composition were most affected by increasing biomass of the earthworm species Lumbricus rubellus. Where L. rubellus was absent there was a diverse community of native herbaceous plants, but where L. rubellus biomass reached its maximum, the herbaceous-plant community was dominated by Carex pensylvanica and Arisaema triphyllum and, in some cases, was completely absent. Evidence from these forest sites suggests that earthworm invasion can lead to dramatic changes in the understory community and that the nature of these changes is influenced by the species composition of the invading earthworm community.
\end{abstract}

Key words: Acer saccharum; earthworm invasion; ecosystem change; exotic species invasion; Lumbricidae; northern hardwood forests; tree seedlings; understory plant communities.

\section{INTRODUCTION}

The effect of individual species on ecosystem function varies greatly (Vitousek 1986, Pastor et al. 1999). Most exotic species have little effect, but a few can alter ecosystem properties and, by changing habitats for all other species, create a new community structure (Vitousek 1990). The hardwood forests of the western Great Lakes region, USA (Minnesota, Wisconsin, and Michigan), developed without native earthworms (James 1995). The introduction of European earthworms (Lumbricidae) represents a major change in the detritivore community in these forests. Invasions of European earthworm species have accelerated during the last few decades via the widespread use of earthworms as bait for recreational fishing (Gates 1982). Because the forested part of the region has many lakes used for fishing (33000 in Minnesota, Wisconsin, and Michigan), there are many centers of infestation at this time. Nearly all forests have been invaded in the

Manuscript received 5 November 2004; revised 6 October 2005; accepted 17 November 2005; final version received 10 January 2006. Corresponding Editor: P. J. Bohlen.

${ }^{1}$ Present address: Natural Resources Research Institute, University of Minnesota at Duluth, 5013 Miller Trunk Highway, Duluth, Minnesota 55811-1442 USA.

E-mail: cmhale@d.umn.edu southern part of the region, where human activity has been most intense for the longest period of time (C. M. Hale and L. E. Frelich, personal observations). In contrast, many hardwood forests in the northern areas of the region remain worm-free (Alban and Berry 1994, Holdsworth et al. 2004, Hale et al. 2005a).

Without earthworms, northern hardwood forests develop a thick forest floor and microbes (i.e., bacteria and fungi) apparently control the rate of recycling and nutrient availability rather than large invertebrates such as earthworms (Bormann and Likens 1979, McClaugherty et al. 1985, Aber et al. 1990). Therefore, northern hardwood forests of the Great Lakes region may be particularly predisposed to experience large impacts when earthworms invade. Earthworms, as detritivores, survive in the forest by eating leaf litter, soil organic matter, and associated microorganisms, thereby changing physical, chemical, and biotic characteristics of the forest floor and upper soil horizons.

The forest floor serves as a physical substrate and rooting medium for an entire community of native plant species, including tree seedlings and understory plants. Forest ecologists have only recently given major attention to the possibility that the community of soil organisms may have a greater level of control over forest plant community dynamics than had been supposed in the past (Ponge et al. 1998, Watkinson 1998). Although 

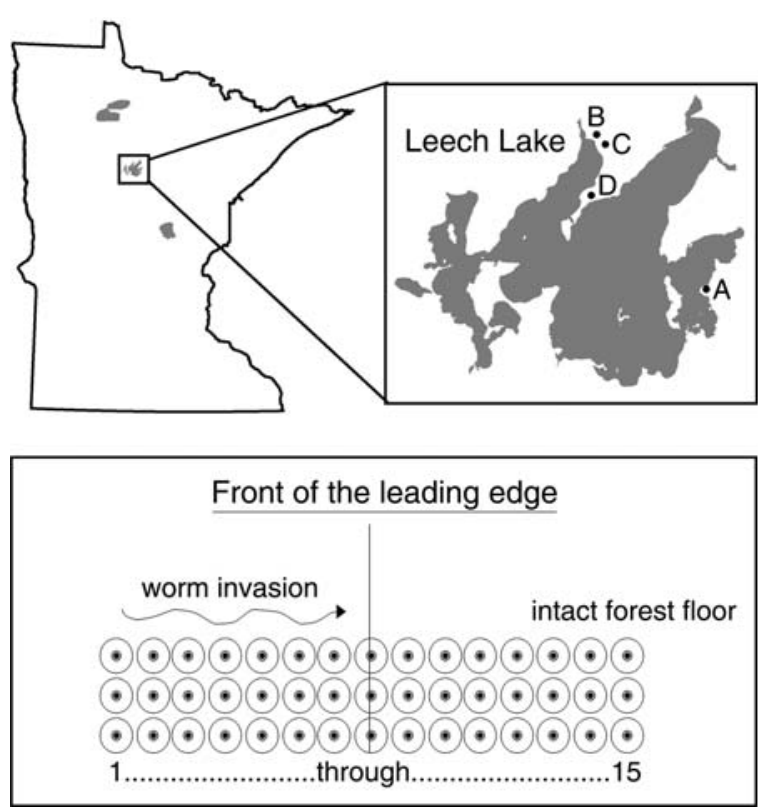

FIG. 1. Locations of the four study sites ( $\leq 6 \mathrm{~km}$ apart) in the Chippewa National Forest near Leech Lake in north central Minnesota, USA. Letters A, B, C, and D indicate sites Blackduck, Ottertail, Section 19, and Two Points, respectively. An illustration of the sample grid $(30 \times 150 \mathrm{~m})$ of 45 points laid perpendicular to the leading edge of earthworm invasion in each study site is given; sample points are $10 \mathrm{~m}$ apart.

invasions of European earthworm species (Lumbricidae) are widespread throughout cold-temperate forests in North America, only a few studies have documented their impacts on previously earthworm-free native ecosystems (McLean and Parkinson 1997, Bohlen et al. $2004 a$ ).

\section{Effects of earthworm invasion on plant communities}

The forest floor in northern temperate hardwood forests is the substrate in which most nutrient transformation occurs; provides habitat for a diverse community of decomposers, fungi, arthropods, and small vertebrates; and is the seedbed for all forest plant species. When the forest floor is removed, a cascade of changes in the ecosystem follows, including changes in understory plant communities (Gundale 2002). Earthworms are capable of burying large quantities of organic material and causing disappearance of the forest floor layer through direct consumption, redistribution of organic material within the soil, and increasing decomposition rates (Nielsen and Hole 1963, Devliegher and Verstraete 1997). Direct mortality of herbaceous plants and small tree seedlings that were rooted in the forest floor layer prior to earthworm invasion occurs when earthworms eat the forest floor out from under them (James and Cunningham 1989, Hale 2004). Plant regeneration may decrease due to direct ingestion and deep burial of seeds by earthworms and by loss of the sheltering forest floor layer, exposing seeds and seedlings to desiccation and predation by insects, small mammals, and other organisms (Leck 1989). After initial earthworm invasion, smaller understory plant populations may become more vulnerable to the impacts of deer grazing, which could lead to local extirpation (Augustine et al. 1998). Changes in soil chemical composition and nutrient dynamics have been documented following invasion in previously earthworm-free soils (Scheu and Parkinson 1994, Tomlin et al. 1995), including increases in $\mathrm{N}$ and $\mathrm{P}$ loss due to leaching and decreased $\mathrm{N}$ and $\mathrm{P}$ availability (Bohlen et al. 2004b, Suárez et al. 2004, Hale et al. 2005b). Finally, changes in soil microbial communities, in particular changes in mycorrhizal fungi associations, may lead to declines in native understory plant abundance and diversity (Francis and Read 1994, Groffman et al. 2004).

There are many leading edges of European earthworm invasion across northern Minnesota and the Great Lakes region (Holdsworth et al. 2004). Across these leading edges there are often rapid increases in total earthworm biomass, the successive appearance of up to eight earthworm species, and substantial changes in soil physical and chemical properties (Hale et al. 2005a, b). The magnitude and rate of loss of forest floor mass depends on the biomass, species composition, and activity level of the earthworm populations (Springett 1983, Hale et al. 2005a, b). Species such as Lumbricus rubellus, which are responsible for the most rapid removal of the forest floor may have the greatest impact on plant communities during initial invasion (Hendriksen 1990, Gundale 2002, Hale et al. 2005b). The gradient of earthworm species and changes in soil characteristics across the leading edges within forest stands provides an opportunity to assess the relationships of earthworm biomass and species assemblages to changes in the understory plant community while controlling sitespecific factors that often confound field-based comparative studies.

The objectives of this study were to describe the relationships of earthworm biomass and species composition with the abundance, diversity, and composition of the understory plant community across leading edges of earthworm invasion. We hypothesized that (1) increasing total worm biomass would be associated with decreases in herbaceous-plant abundance and diversity and tree seedling density; (2) increasing biomass of the epiendogeic species L. rubellus would be the most strongly related to changes in herbaceous-plant composition.

\section{Methods}

The study was conducted over four years (1998-2001) in four mature northern hardwood stands that contain leading edges of earthworm invasion located in the Chippewa National Forest of northern Minnesota (Fig. 1). The four study sites are 1-6 km apart and have similar overstory composition, topography, soils, and stand history. Sugar maple (Acer saccharum, Marshall) is the dominant tree species, with yellow birch (Betula 
alleghaniensis, Britton), paper birch (Betula papyrifera, Marshall), and basswood (Tilia americana, Linnaeus) as secondary species. Soils are a deep, well-drained, and light-colored Eutroboralf associated with the Guthrie Till Plain (USDA 1997) and, under worm-free conditions, are characterized by a thick forest floor (mean of $7 \mathrm{~cm}$; Hale et al. 2005a) composed of $\mathrm{O}_{i}, \mathrm{O}_{\mathrm{e}}$, and $\mathrm{O}_{\mathrm{a}}$ layers. The climate is humid, continental, cold temperate with $65 \mathrm{~cm}$ mean annual precipitation. The median growing season is $134 \mathrm{~d}$, with snow cover from late November to early April and mean temperatures in January and July of $-15^{\circ}$ and $20^{\circ} \mathrm{C}$, respectively (Hale et al. 2005b; Minnesota State Climatology Office, data available online). ${ }^{2}$

During site selection, a leading edge of earthworm invasion was defined as a visually discrete area in the forest where a transition from a thick forest floor to a thin forest floor took place within 75-100 m (Hale et al. $2005 b$ ). In each site, a $30 \times 150 \mathrm{~m}$ sample grid was established consisting of 45 sample points $10 \mathrm{~m}$ apart in three parallel transects with 15 points each (Fig. 1). Transects were placed perpendicular to the leading edge with sample point 8 at the approximate front of the leading edge.

\section{Vegetation sampling}

Each sample point was the center of a set of three nested subplots established for vegetation sampling (Fig. 1). For each study site in the first and last year, the species diameter at breast height $(\mathrm{dbh}$, breast height $=$ $1.4 \mathrm{~m}$ above the ground surface) and height of all trees $\geq 10 \mathrm{~cm}$ dbh were recorded within a $4.5 \mathrm{~m}$ radius subplot. In the fall of each year, saplings, seedlings, and shrubs were sampled in a $1.75 \mathrm{~m}$ radius subplot. All saplings (tree species $<10 \mathrm{~cm} d b h$ ), seedlings, and shrubs were tallied by species, and the total percent cover for each species was recorded. In a $0.75 \mathrm{~m}$ radius subplot, all herbaceous and graminoid species were identified, and the number and total percent cover of each were recorded.

\section{Earthworm sampling}

In fall 1999 and 2000 the earthworm populations were censused using a mustard solution extraction procedure in $0.12-\mathrm{m}^{2}(35 \times 35 \mathrm{~cm})$ subplots located $2.0 \mathrm{~m}$ from each sample point at a randomly selected cardinal direction (Zaborski 2003, Hale et al. 2005a). Previous comparisons of earthworm biomass measures from hand sampling and mustard extraction sampling were well correlated (Hale et al. 2005a). For each subplot, total earthworm biomass (ash-free dry mass, AFDM) was determined for each species (Hale et al. 2004). For the purposes of statistical analysis, earthworm species were assigned to one of six taxonomic groups, including Dendrobaena octaedra, Lumbricus rubellus (adults), L.

\footnotetext{
${ }^{2}\langle$ http://climate.umn.edu $\rangle$
}

terrestris (adults), Lumbricus species (juveniles), Aporrectodea species, and Octolasion tyrtaeum (Hale et al. $2005 b$; see Plate 1).

\section{Analytical methods}

For all analyses, the two-year mean (1999 and 2000) of earthworm biomass per sample point was used as the best measure of mean earthworm biomass for each sample point ( $n=45$ in each site; Hale et al. 2005b). For purposes of statistical analysis, earthworm biomass data were log-transformed using a technique described in McCune and Grace (2002) that preserves zero values and differences in magnitude that exist in the data set (Hale et al. 2005b). The transformed value $(b)$ is calculated as follows:

$$
b=\log _{10}(x+d)-c
$$

where $c$ is the the integer of $\log _{10}[\min (x)], \min (x)$ is the lowest nonzero value of $x$, and $d$ is the inverse $\log _{10}(c)$.

\section{Plant community relationships with earthworm biomass}

For sapling, seedling, shrub, and herbaceous-plant total cover and diversity, the two-year mean from 1999 and 2000 was used in analyses with the two-year mean of earthworm biomass for each sample point. Trees and snag data from 2001 were analyzed in relation to the two-year mean of total earthworm biomass. The Shannon-Weaver $\left(H^{\prime}\right)$ index of diversity and the Simpson's $(D)$ index of dominance (Shannon and Weaver 1964, Magurran 1988) were calculated for the herbaceous-plant community. Tree, snag, and seedling density along with herbaceous-plant richness were log transformed $[x=\ln (x+1)]$ to preserve zeros and normalize the data distributions prior to analysis. All percent cover data were converted to ordinal cover classes (Host and Pregitzer 1991, McCune and Grace 2002), which normalized the data distributions, and no further transformations were required. A combination of multiple and simple linear regression analyses were used to assess the relationship of total earthworm biomass to changes in tree, sapling, shrub, and herbaceous-plant total cover and diversity measures (SAS Institute 2001).

The composition of tree, sapling, shrub, and herbaceous-plant communities in relation to earthworm species-specific biomass was assessed using nonmetric multidimensional scaling (NMS) ordination with Sorenson's distances (McCune and Grace 2002) in PCORD (McCune and Mefford 1999). Ordinations of the herbaceous-plant community $(n=180)$ were conducted with the rarest plant species $(n \leq 3)$ and strong outliers $(>2.6 \mathrm{SD})$ deleted. Preliminary NMS analysis with 50 runs of real data and 100 runs with randomized data for a Monte Carlo test of significance were conducted. The optimal number of ordination dimensions was determined based on the lowest stress achievable with the fewest number of dimensions. A series of secondary NMS analyses were conducted with the designated number of ordination dimensions, 50 runs of real data, 


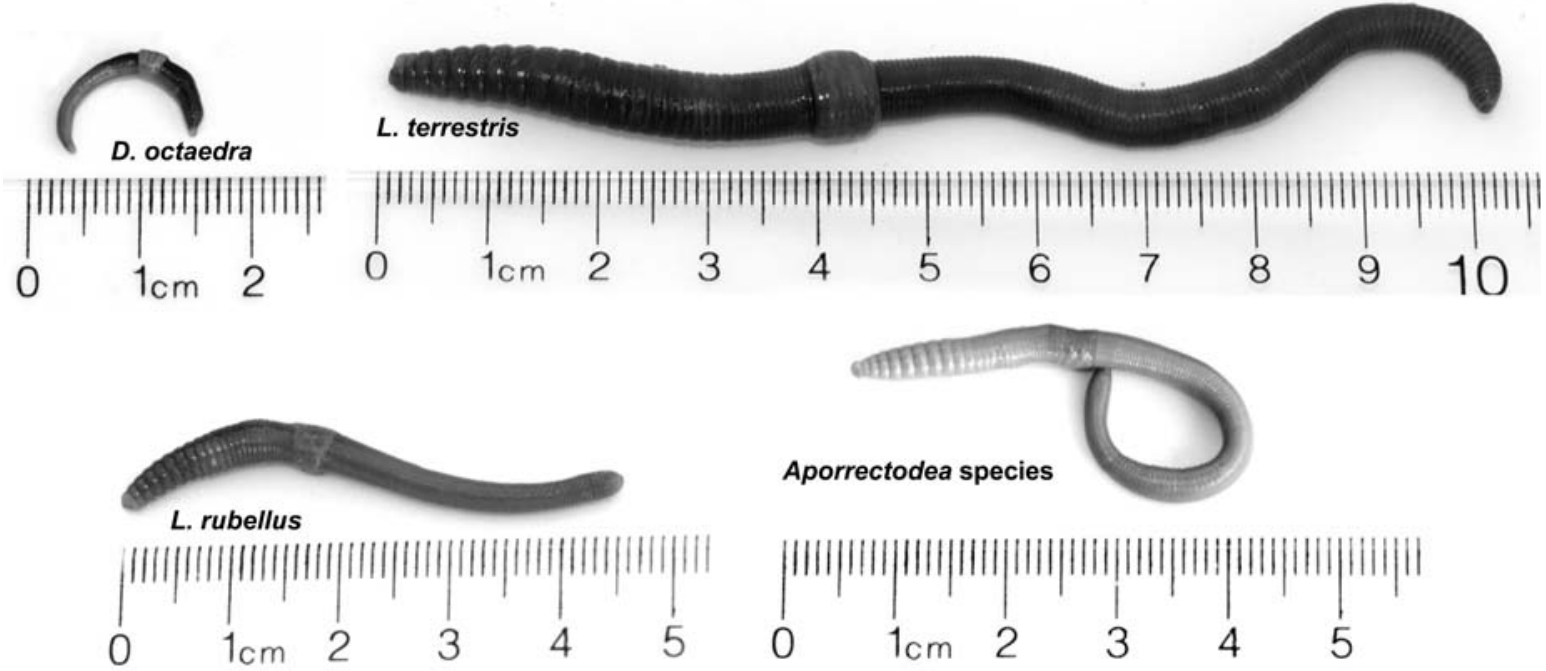

Plate 1. Ecological groups of commonly seen exotic earthworms. (Top left) Epigeic species, such as Dendrobaena octaedra, are small-bodied pigmented earthworms that live and feed exclusively in the surface litter above the mineral soil. They feed primarily on microorganisms and fungi associated with the litter layer but do not actively mix surface litter into the mineral soil. (Top right) Anecic species, such as the common night crawler (Lumbricus terrestris), are large-bodied pigmented species that form vertical burrows up to $2 \mathrm{~m}$ deep but feed on fresh surface litter. (Lower left) Epi-endogeic species, such as Lumbricus rubellus, are moderately sized pigmented earthworms that live in the surface litter and the top $2-4 \mathrm{~cm}$ of soil, making no permanent burrows. They feed on surface litter and actively mix organic material into the surface soil horizon. (Lower right) Endogeic species, such as Aporrectodea species, are small- to large-sized unpigmented earthworms that form extensive branching burrow systems in the top $50 \mathrm{~cm}$ of soil. They feed by ingesting large amounts of soil and digest the soil organic matter and microorganisms found there. Photo credit: C. Hale.

and 100 runs with randomized data. When consistent results after multiple runs from a random starting configuration were found, the secondary analysis with the lowest stress and final instability was used as the starting configuration for the final NMS analysis reported here. Environmental variable overlays were used to assess the relationship of site, sample point position, and earthworm species-specific biomass to the ordination of the herbaceous-plant community.

Additionally, the multi-response permutation procedure (MRPP) was used to test the hypothesis that the overall herbaceous-plant communities among the four study sites were the same (PC-ORD, McCune and Mefford 1999), so that we could be confident that any gradient of changes in plant communities in response to earthworm communities were not simply artifacts of site differences. The MRPP is a nonparametric procedure that compares the observed weighted mean within-group distance (delta) to the expected distribution of delta (Mielke and Berry 2001, McCune and Grace 2002). A p value, indicating the probability that the observed difference is due to chance, and an agreement statistic $(A)$, which indicates the degree to which groups differ from that expected by chance, are generated.

\section{Plant community relationships with earthworm species assemblages}

Herbaceous-plant community richness and speciesarea relationships were compared among sample points with different earthworm species assemblage groups. Using a combination of cluster analysis and indicator species analysis, four earthworm species assemblage groups were identified (Hale et al. 2005b), and each sample point was assigned to one of the four species assemblage groups.

Herbaceous-plant community richness was compared among earthworm assemblage groups using Whittaker's (1972) alpha and gamma diversity measures. Alpha diversity is calculated as the mean herbaceous-species richness per sample point in each earthworm assemblage group. Gamma diversity is the landscape-level diversity and is estimated as the total number of herbaceous species across all points in each earthworm assemblage group.

Species-area curves of the herbaceous-plant community in each earthworm assemblage group were constructed using PC-ORD (McCune and Mefford 1999). In each assemblage group, the sample points were aggregated in every possible combination to produce the mean number of herbaceous species and standard deviation for each possible aggregate size (i.e., number of sample points $=1,2,3 \ldots n)$. The species-area function $S=c A^{z}$ was fit as with

$$
\ln (S)=\ln (c)+z \ln (A)
$$

where $S$ is the mean number of species found in area $A, z$ is the instantaneous rate by which species richness increases with an incremental increase in area, and $c$ is the expected number of species in a single unit area 


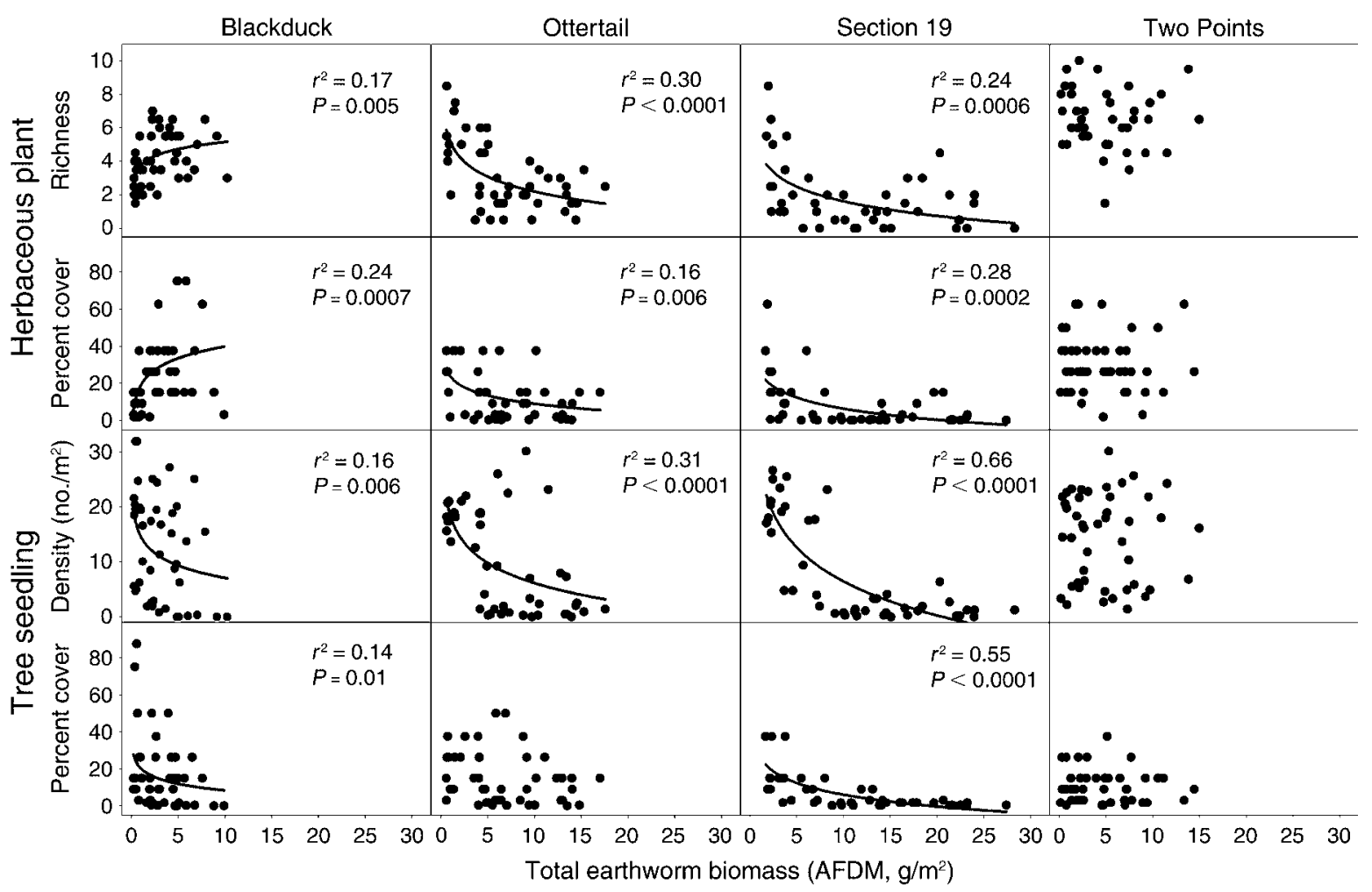

FIG. 2. Scatterplots of herbaceous-plant species richness and total percent cover and sugar maple seedling density and total cover in relation to total earthworm biomass (ash-free dry mass, AFDM) in each study site ( $n=45$ points in each site).

(Arrhenius 1921). It might be assumed that any differences in the shape of species curves between assemblage groups are related primarily to differences in earthworm biomass. To test this hypothesis, the $z$ exponent and the $c$ coefficient values from all groups were regressed against the mean earthworm biomass from each group (Pastor et al. 1996).

\section{RESULTS}

Plant density, total cover, and diversity in relation to total earthworm biomass

Herbaceous plants and maple seedlings in relation to total earthworm biomass. - The relationships of herbaceous-plant species richness and total cover to increasing total earthworm biomass varied among sites $(P<$ 0.0001; Fig. 2). At two sites, herbaceous-plant species richness and cover decreased significantly $(P \leq 0.006)$ with increasing worm biomass, whereas at a third they increased with worm biomass $(P \leq 0.005)$, and there was no relationship at the fourth. The Shannon-Weaver $\left(H^{\prime}\right)$ index of diversity and Simpson's $(D)$ index of dominance had the same relationships as species richness to earthworm biomass and sites $(P \leq 0.03)$. Sugar maple seedling density and total cover decreased with increasing total earthworm biomass $(P<0.0001)$ in three of four sites (Fig. 2).

Trees, snags, saplings, and shrubs in relation to total earthworm biomass.-Among all sites and sample points, there were no consistent relationships of the density and basal area of trees or snags $(>10 \mathrm{~cm} \mathrm{dbh})$ to total earthworm biomass. The density of trees ranged from 157 to 1258 stems/ha, and the density of snags ranged from 0 to 471 stems/ha. The basal area of trees ranged from 0 to $184 \mathrm{~m}^{2} /$ ha (mean $32 \mathrm{~m}^{2} /$ ha) and the basal area of snags ranged from 0 to $87 \mathrm{~m}^{2} /$ ha (mean $6 \mathrm{~m}^{2} / \mathrm{ha}$ ).

Among all sites and sample points, there were no consistent relationships between total earthworm biomass and total cover of large saplings, seedlings, shrubs, or the density of dead saplings. The total cover of small saplings $(\geq 0.5 \mathrm{~m}$ tall to $<2 \mathrm{~cm} \mathrm{dbh})$ increased with total earthworm biomass $(P=0.02)$ in one of the four study sites (Section 19).

\section{Earthworm species and assemblage groups in relation to sites}

Earthworm species, assemblage groups, and relative biomass differed among the four study sites (Fig. 3; Hale et al. 2005a, b). Of the six taxonomic groups found in this study, two were found in all four sites, including $D$. octaedra (epigeic) and Aporrectodea species (endogeic). In all sites, these taxonomic groups exhibited distinct differences in relative abundance across the leading edges, with $D$. octaedra most abundant in front of the visible leading edge (at approximately plot 8) in areas with some intact forest floor (at approximately plots 1115) and with Aporrectodea the most abundant behind 


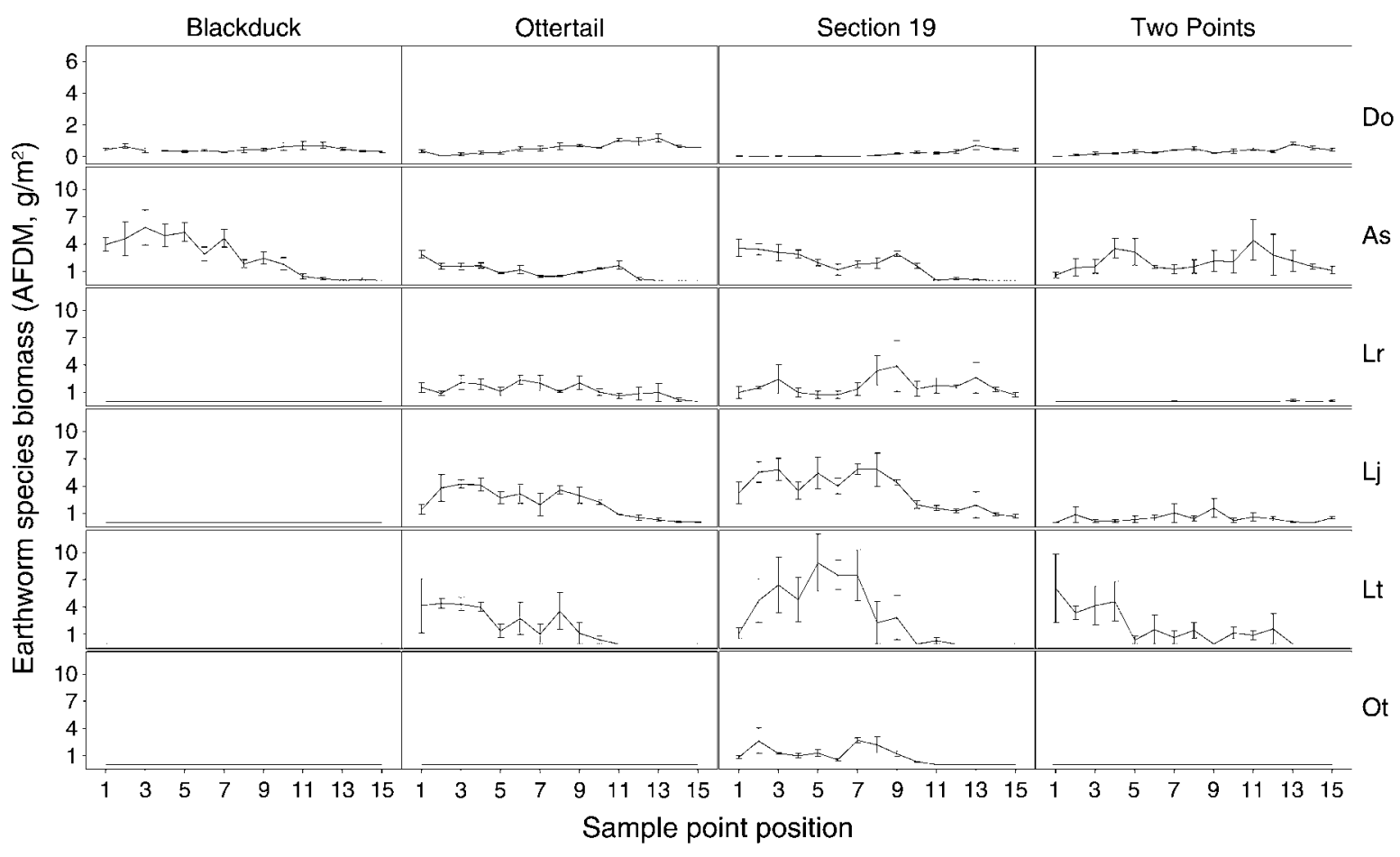

FIG. 3. Scatterplots of earthworm ash-free dry mass (mean $\pm \mathrm{SE}$ ) in 1999-2000 for each taxonomic group in relation to sample point position for each study site. Taxa (given to the right of each row of plots) are: Do, Dendrobaena octaedra; As, Aporrectodea species; Lr, Lumbricus rubellus (adults); Lj, Lumbricus species (juveniles); Lt, Lumbricus terrestris (adults); Ot, Octolasion tyrtaeum. For Do plots, the $y$-axis scale differs from all other plots so that the graphs of this small-bodied species are more visible and comparable among sites.

the leading edge (except in the Two Points site). Lumbricus terrestris (adult), an anecic species, was found in three of the four sites, but it was generally absent in front of the leading edge with increasing abundance behind the leading edge. Lumbricus rubellus (adult), an epi-endogeic species, was found in two of the four study sites and spanned the sample grids. Lumbricus (juveniles) were found in three of the four sites. In the Two Points sites, where L. rubellus was not present, Lumbricus juveniles are assumed to be L. terrestris. However, in the Ottertail and Section 19 sites, Lumbricus juveniles are a mixture of $L$. rubellus and $L$. terrestris and were more abundant behind the leading edge (Fig. 3).
Earthworm assemblage groups, as determined by cluster analysis and indicator species analysis (see Methods), represented the presence or absence of a taxonomic group as well as their relative abundance (Table 1, Fig. 4). Species assemblage group 1 contained sample points with the taxonomic group Dendrobaena octaedra only $(n=21)$ and was present in two of the four study sites (Blackduck and Ottertail). Species assemblage group 2 contained sample points with the taxonomic groups Lumbricus rubellus (adults), Lumbricus (juveniles), and Dendrobaena octaedra $(n=13)$ and was present in two of the four study sites (Ottertail and Section 19). Species assemblage group 3 contained sample points with the taxonomic groups Aporrectodea

TABLE 1. Herbaceous-plants species richness in relation to earthworm species assemblage groups and mean total ash-free dry biomass (AFDM) of earthworms for each group.

\begin{tabular}{|c|c|c|c|c|}
\hline $\begin{array}{l}\text { Earthworm assemblage } \\
\text { dominant species }\end{array}$ & $n$ & $\begin{array}{l}\text { Total earthworm } \\
\text { biomass }\left(\mathrm{AFDM}, \mathrm{g} / \mathrm{m}^{2}\right) \dagger\end{array}$ & $\begin{array}{l}\text { Sample point } \\
\text { mean richness: }\end{array}$ & $\begin{array}{l}\text { Total group } \\
\text { richness } \oint\end{array}$ \\
\hline Group 1, Dendrobaena octaedra & 21 & $0.73(0.45)$ & $4.45^{\mathrm{A}}$ & 36 \\
\hline Group 2, Lumbricus rubellus & 13 & $2.95(1.69)$ & $4.35^{\mathrm{A}}$ & 26 \\
\hline Group 3, Aporrectodea species & 75 & $4.37(3.17)$ & $5.60^{\mathrm{B}}$ & 44 \\
\hline Group 4, Lumbricus terrestris & 71 & $10.82(5.99)$ & $1.95^{\mathrm{C}}$ & 35 \\
\hline All plots combined & 180 & $6.42(5.71)$ & $3.94^{\mathrm{A}}$ & 58 \\
\hline
\end{tabular}

Note: Assemblages are described in Methods; $n$ is the number of sample points where the particular assemblage is dominant.

$\uparrow$ Values in parentheses are standard deviations.

\$ Alpha diversity as described by Whitaker (1972). Means with different letters are significantly different $(P<0.05)$.

$\S$ Gamma diversity as described by Whittaker (1972). 


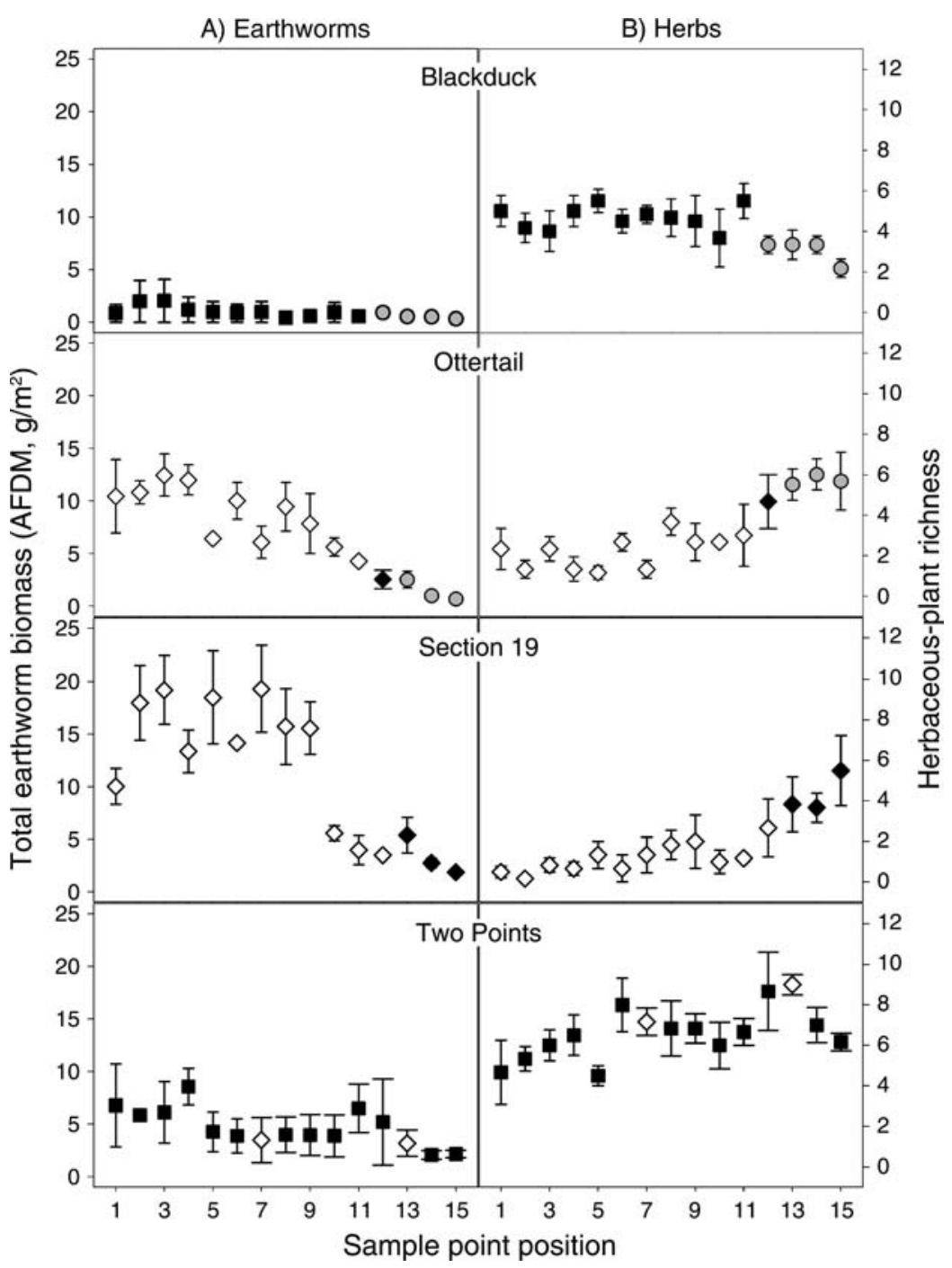

FIG. 4. Scatterplots of (A) earthworm ash-free dry mass (mean $\pm \mathrm{SE}$ ) and (B) herbaceous-plant richness in relation to sample point position (points are $10 \mathrm{~m}$ apart) for each study site in 1999-2000. Symbols represent the dominant earthworm assemblage group at each sample position along the sample grid (occasionally the assemblage group varied among transects within a site for a given sample point position); gray circles are sample points with Dendrobaena octaedra only $(n=21)$; solid diamonds are sample points with Lumbricus rubellus (adults), Lumbricus (juveniles), and Dendrobaena octaedra $(n=13)$; solid squares are sample points dominated by Aporrectodea species and Dendrobaena octaedra $(n=75)$; and open diamonds are plots with all taxonomic groups present but identified by the abundance of Lumbricus terrestris $(n=71)$.

species and Dendrobaena octaedra as the dominant species with occasional Lumbricus rubellus (adults) and Lumbricus (juveniles) $(n=75)$ and was present in two of the four study sites (Blackduck and Two Points). Species assemblage group 4 was identified by the presence of Lumbricus terrestris (adults) but contained all other taxonomic groups as well $(n=71)$ and was common in two of the four study sites (Ottertail and Section 19) and occasionally present in the Two Points site (Fig. 4). Mean total biomass of the plots dominated by the $L$. terrestris assemblage group was much greater than in plots with other species assemblages (Table 1, Fig. 4).

\section{Herbaceous-plant richness in relation to earthworm species assemblage groups}

Mean herbaceous-plant richness per sample point was lower in plots with earthworm assemblages dominated by $L$. terrestris, compared with the other assemblage groups and all sample points combined (Table 1, Fig. 4). Although there were three times as many plots dominated by L. terrestris as by D. octaedra, total plant species richness was comparable in these two groups of plots (Table 1). Similar numbers of plots were dominated by the Aporrectodea and the L. terrestris earth- 


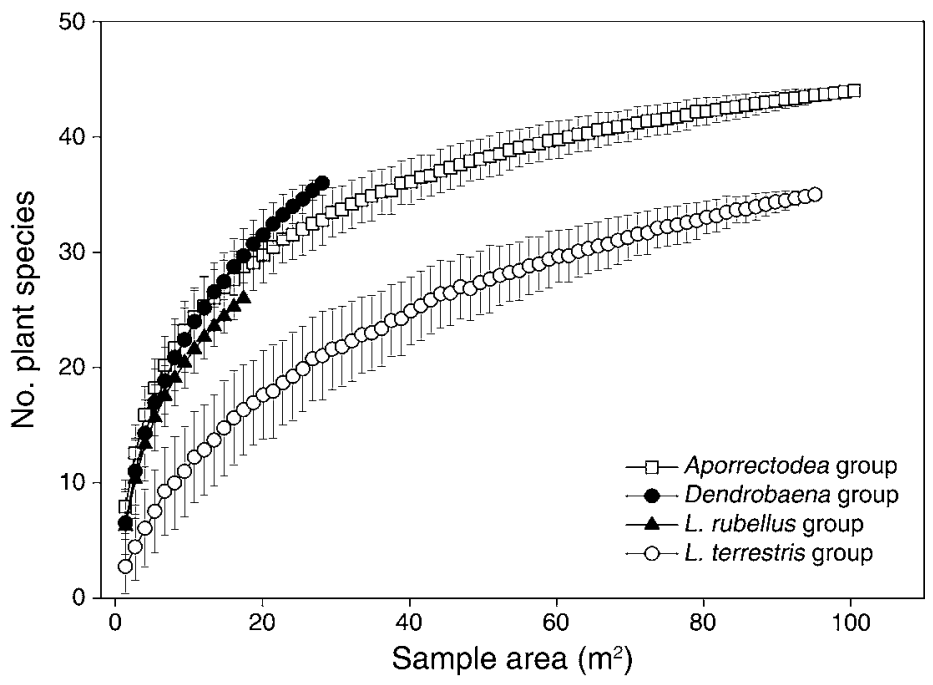

FIG. 5. Species-area curves: herbaceous-plant species richness (mean \pm SD) in plots dominated by differing earthworm assemblages. Solid circles are sample points with Dendrobaena octaedra only $(n=21)$; solid triangles are sample points with Lumbricus rubellus (adults), Lumbricus (juveniles), and Dendrobaena octaedra $(n=13)$; open squares are sample points dominated by Aporrectodea species and Dendrobaena octaedra $(n=75)$; and open circles are plots with all taxonomic groups present but identified by the abundance of Lumbricus terrestris $(n=71)$.

worm groups, but the former contained more plant species.

The species-area curve of plots dominated by $L$. terrestris fell below the curves of plots with other earthworm species assemblage groups (Fig. 5). Although the species curves of the Aporrectodea, Dendrobaena, and $L$. rubellus assemblage groups overlapped where sample area was small, near $15 \mathrm{~m}^{2}$ the Dendrobaena group curve crossed that of Aporrectodea on a trajectory of increasing plant species richness compared to all other groups and the L. rubellus group begins to fall below the curve of Aporrectodea. Regression of the $z$ exponent and the $c$ coefficient values against mean earthworm biomass from each group resulted in no significant correlation,

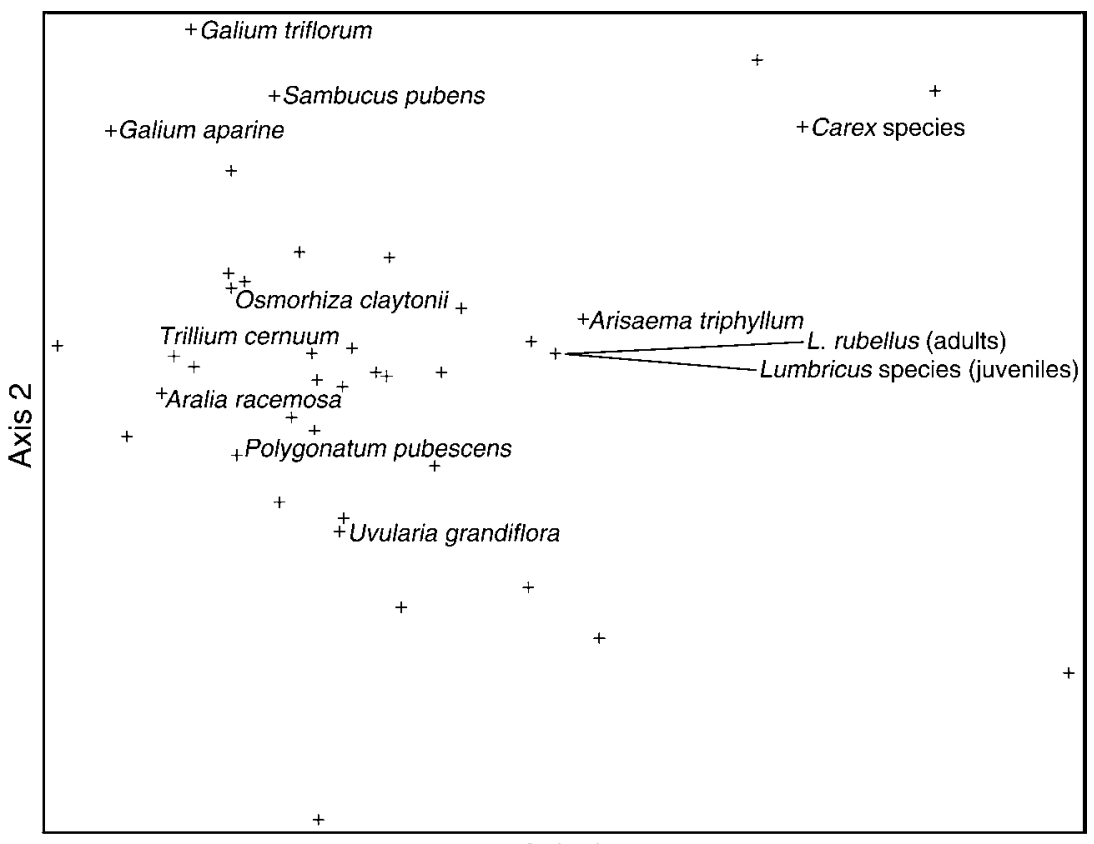

\section{Axis 1}

FIG. 6. Nonmetric multidimensional scaling ordination of herbaceous-plant species $(n=180)$ with joint plot overlay of earthworm species biomass vectors for any species with $r^{2}>0.250$ (Lumbricus rubellus and Lumbricus species, $r^{2}>0.450$ ). Selected plant species names are listed to the right of the species symbol $(+)$. 
TABLE 2. Correlation coefficients (Pearson $r$ ) of earthworm species biomass with ordination axis.

\begin{tabular}{lrrr}
\hline \hline Earthworm analytical groups & \multicolumn{1}{c}{ Axis 1 } & Axis 2 & Axis 3 \\
\hline Dendrobaena octaedra & -0.459 & -0.143 & 0.176 \\
Aporrectodea species & 0.038 & 0.219 & -0.097 \\
Lumbricus rubellus (adults) & 0.694 & 0.094 & -0.025 \\
Lumbricus species (juveniles) & 0.682 & 0.037 & 0.099 \\
Lumbricus terrestris (adults) & 0.424 & 0.033 & -0.031 \\
Octolasion tyrtaeum & 0.493 & 0.151 & -0.250 \\
Total earthworm biomass & 0.490 & 0.194 & -0.036 \\
\hline
\end{tabular}

thereby rejecting the hypothesis that changes in $z$ and $c$ among earthworm species assemblage groups are the result of changes in total earthworm biomass.

\section{Plant composition in relation to biomass of earthworm species}

Tree, sapling, seedling, and shrub composition.-The tree, sapling, and seedling populations were strongly dominated by Acer saccharum, and their species composition did not change in relation to either earthworm species or total biomass. The shrub community had $<5 \%$ total cover on average and was composed of six species, including, in decreasing relative abundance, Prunus virginiana (by far the most common), Ribes cynosbati, Lonicera canadensis, Cornus alternifolia, Corylus cornuta, and Dirca palustris.

Herbaceous-plant community composition.-In MRPP analysis, the significant differences in overall herbaceous-plant composition among the four sites were small ( $A \leq 0.16 ; P \leq 0.01$ ). However, the compositional differences among the four sites overall were quite small in comparison to the differences associated with earthworm biomass described below.

Nonmetric multidimensional scaling ordination of herbaceous-plant species resulted in an optimal threedimensional solution (final stress $=19.37656$, final instability $=0.00239$ ) with cumulative proportion of variance represented by the three-dimensional ordination of $r^{2}=0.684\left(r^{2}=0.330,0.169\right.$, and 0.184 for axis 1 , 2 , and 3, respectively). Monte Carlo tests resulted in final stress values well below the range of those of the randomized data set, indicating that the ordination is significantly different than that expected by chance.

Axis 1 represents a shift in herbaceous-plant community associations related to increasing earthworm biomass, particularly with increasing L. rubellus (adults) and Lumbricus species (juveniles) biomass (Fig. 6). Along axis 1 the herbaceous-plant community shifts from one of high diversity when L. rubellus biomass was low to an herb-free or low-diversity plant community dominated by Carex species and Arisaema triphyllum when L. rubellus biomass was high (Fig. 6). Of the 38 herbaceous-plant species included in the ordination, the scores of 32 were negatively correlated with axis 1 relative to the ordination centroid (Appendix A). Polygonatum pubescens and Uvularia grandiflora were absent where L. rubellus abundance was the greatest and were highest in abundance in sample points where $L$. rubellus was absent. This pattern was seen with many other plant species as well (Appendix A). In overlays of earthworm species biomass on the ordination of herbaceous-plant species composition, Dendrobaena octaedra was negatively correlated with axis 1 and the Aporrectodea species group had no correlation with axis 1. All other earthworm species groups and total earthworm biomass were positively correlated with axis 1 , with increasing strength in the order L. terrestris (adults), total earthworm biomass, O. tyrtaeum, $L$. species (juveniles), and L. rubellus (adults) (Table 2).

Axes 2 and 3 represent a disturbance gradient in the herbaceous-plant community on the Blackduck site because of a blowdown in 1999 that decreased overstory canopy cover by $30 \%$. This gradient is indicated by high abundance of Sambucus pubens and Galium triflorum (Fig. 6, Appendix A). Axis 2 has a moderate correlation with the earthworm group Aporrectodea species, and axis 3 has no strong correlations with earthworm species biomass (Table 2).

\section{Discussion AND CONCLUSIONS}

Earthworm invasions were associated with significant changes in the understory plant communities in these sugar maple-dominated hardwood forests. The abundance and richness of the herbaceous-plant community in these forests decreased with increasing total earthworm biomass in two of four sites (Fig. 2), and the density of tree seedlings decreased in three of four sites. Sample points with earthworm species assemblages containing all taxonomic groups, identified by the abundance of L.terrestris (adults), had by far the lowest total plant richness (Table 1, Fig. 4) and slower accumulation of plant species with increasing sample area (Fig. 5).

The changes in species-area relationships among different earthworm assemblages were not solely the result of increasing earthworm biomass, as indicated by the lack of significant correlations in regressions of the $z$ exponent and the $c$ coefficient values against mean earthworm biomass for earthworm assemblage groups. This shows that even though increasing earthworm species diversity is often associated with increasing earthworm biomass, the impact of a species is not always directly related to their biomass (Hale et al. 2005b). Increased earthworm diversity may be more important than biomass alone because multiple species represent multiple feeding and burrowing behaviors (i.e., epigeic, epi-endogeic, endogeic, anecic; Bouché 1977, Hendrix et al. 1999). Furthermore, synergistic relationships among different species may lead to larger impacts when they are found together (Lavelle 1997). For example, in our sugar maple-dominated forests, Aporrectodea species do not appear to consume unaltered forest floor material. However, once the forest floor has been somewhat humified by epigeic species (i.e., $D$. 
octaedra, L. rubellus), the forest floor is rapidly removed by Aporrectodea (Hale et al. 2005a).

Increasing biomass of L. rubellus, which contributed less to total biomass than did Aporrectodea species or $L$. terrestris, had the greatest effects on understory plant species composition (Fig. 6, Appendices A, B). Where $L$. rubellus was absent there was a diverse community of herbaceous plants, including Caulophyllum thalictroides, Uvularia grandiflora, Trillium species, Osmorhiza claytonii, Asarum canadensis, and Polygonatum pubescens, which are often used a indicators of rich sugar mapledominated hardwood forests in our region (Aaseng et al. 1993, Kotar et al. 2002). These indicators were present even in some instances in which there was high biomass of earthworm species other than L. rubellus (Appendix B). Where L. rubellus biomass reached its maximum, the herbaceous-plant community was dominated by Carex pensylvanica and Arisaema triphyllum, with rare occurrences of other native plant species, and in some instances was entirely absent.

The large effect of the relatively small-bodied (low biomass) species L. rubellus illustrates the need to consider specific feeding and burrowing behavior when assessing potential impacts of any particular invading earthworm species (Gundale 2002, Hale et al. 2005a; Callaham et al., in press). As a generalist feeder $L$. rubellus burrows and casts in the surface mineral soil layer (Rozen 1988, Edwards et al. 1995, Hendrix et al. 1999) and is commonly associated with plant roots, likely feeding in the rhizosphere (C. M. Hale, personal observations). Furthermore, the effects of L. rubellus on native understory forest plant species is associated with the rapid loss of the forest floor that occurs when this species is present, suggesting that this species adds a strong, short-term effect on plant communities that may not occur in its absence.

\section{Site differences in earthworm populations}

The relative impacts of exotic earthworm invasion on hardwood forest understory plant communities depends, in part, on the specific earthworm assemblage present in a given site (Figs. 4, 5, and 6; Gundale 2002, Bohlen et al. 2004a, Hale et al. 2005a, b). In northern hardwood forests of Minnesota, earthworm assemblages in any given area are related to the time since initial invasion, the probability that any given species is present in the source population, and the ability of a given species to survive and reproduce. The consistency in litter quality, soil, and climatic conditions among our study sites indicates that all earthworm species detected in this study have the ability to survive in all four sites. Therefore, the differences in earthworm assemblages associated with sites are the result of the time since initial invasion at a given sample point (Hale et al. $2005 \mathrm{~b}$ ) and the species composition of the local source populations. In areas with only incipient invasions, Dendrobaena is often the only species present (Figs. 3 and 4; Gundale 2002, Hale et al. 2005a), due to its ability to colonize intact forest floor in advance of other invading species. In sites that have been invaded for long periods of time, earthworm populations often contain a full suite of species including epigeic, epi-endogeic, endogeic, and anecic species. However, some sites contain a more limited set of species apparently because all species have not yet gained access to the site.

Fishing bait is apparently the most important source of exotic earthworm introductions in our study area. Therefore, road access and the intensity of fishing activities are important factors affecting the probability that different species have reached a given site. For example, our Blackduck site (Fig. 1) is relatively remote with poor road access and as a result contains only two species of earthworms. By contrast the Ottertail and Section 19 sites, both of which have more diverse earthworm communities than the Blackduck site, have direct access from a heavily traveled, paved road and are adjacent to a large fishing resort established in the 1950s. Like the Blackduck site, the Two Points site is somewhat remote, being near the tip of a long peninsula on a lowtraffic, gravel road. However, Two Points is close to a small fishing camp where the owner worked to establish night crawler populations (L. terrestris) for his clients. As a result this site is dominated by Lumbricus terrestris with other opportunistic species, but does not include $L$. rubellus, the other common bait species used in the area.

\section{Potential mechanisms of earthworm effects on understory plant communities}

Rapid removal of the forest floor during initial earthworm invasion results in increased mortality of the standing crop of native understory plant species as the forest floor is literally eaten out from under them (Hale 2004). Under such circumstances, plants that can rapidly respond to such disturbance by creating new root systems in the developing A horizon and spread vegetatively (i.e., Carex pensylvanica, Asarum canadensis) will be at an advantage. Similarly, small-seeded species that are well adapted for germination and seedling establishment in environments with thin forest floors (i.e., Gallium spp., Allaria petiolata) will be favored over large-seeded native plant species that may have complex seed dormancy requirements (Grime 1979, Kostel-Hughes 1995, Baskin and Baskin 1998).

Plants with high levels of secondary compounds are generally not grazed by herbivores, and their rhizosphere may be avoided by earthworms as well. Root herbivory and changes in the rhizosphere can result in decreases in plant growth and diversity (Brown and Gange 1989, Bever et al. 1997). Arisaema triphyllum (jack in the pulpit) and Allium tricoccum (wild leeks) were positively associated with increasing earthworm biomass and both contain toxic compounds that may inhibit grazing in the rhizosphere by earthworms. Arisaema triphyllum contains oxalic acids, and the roots are reported to be the most toxic part of the plant (Black 1918, Woodcock 1925). Allium tricoccum contains large 
amounts of thiosulfinates and other sulfur compounds that have been shown to be toxic to insects, and they may also be toxic to earthworms (Calvey et al. 1998, Dugravot et al. 2004). While toxic compounds in these species may minimize direct effects of earthworm grazing, changes in soil structure and chemistry may still have effects. For example, both Arisaema triphyllum and Allium tricoccum had their lowest abundances in nearly earthworm-free conditions and where earthworm biomass and diversity were the highest (data not shown), suggesting that an initial enhancement may be occurring early on in the earthworm invasion followed by declines in these species after large, persistent earthworm populations had become established.

Grazing by earthworms can lead to declines in the abundance and changes in the structure of the soil fungal community (Johnson et al. 1992, Scheu and Parkinson 1994). The vast majority of native understory plants in northern temperate sugar maple-dominated forests are strongly mycorrhizal (Brundrett and Kendrick 1988, Baskin and Baskin 1998). Carex pensylvanica is one of a few non-mycorrhizal native species in these forests (Brundrett and Kendrick 1988) and was the dominant herbaceous-plant species in sites where $L$. rubellus biomass and associated rhizosphere disturbance were high. Earthworms have been shown to decrease mycorrhizal colonization rates of sugar maple seedlings (Lawrence et al. 2001), further suggesting that declines in abundance of mycorrhizal fungi or other shifts in the fungal community may be contributing to changes in the understory plant community (Newman and Reddell 1988, van der Heijden et al. 1998).

\section{Broader impacts of earthworm invasions}

Concern over the potential widespread loss of native forest plant species and the loss of stability that could result from earthworm invasion throughout the range of northern hardwood forests suggest that management strategies be developed to either prevent further invasions or provide for restoration following invasion (Proulx 2003). Management and regulatory strategies will need to take into account the fact that some earthworm species, such as L. rubellus, may have larger impacts than others. Lumbricus rubellus is less widely distributed than exotic earthworms in general (Reynolds et al. 2002, Holdsworth et al. 2004), making it more important to prevent its introduction into new areas, even if those areas are already infested with other earthworms. Although local control of invasions may be possible in some situations, the magnitude and regional scale of European earthworm invasions suggest that in the next few decades a majority of hardwood forest will be impacted to some degree by earthworms (Dymond et al. 1997, Bohlen et al. 2004a, Holdsworth et al. 2004). Because of their close proximity to fishing lakes and rivers, hardwood forests in Minnesota may be particularly vulnerable to invasion by a number of exotic earthworm species.
The level of impact in different forest types may vary in relation to site productivity and other drivers of plant community dynamics. For example, it is possible that earthworms could decrease the populations of understory plant species to a level at which high deer densities causes extirpation (Augustine et al. 1998). Therefore, we will need to understand the factors that control or prevent recolonization of native understory species of earthworm-impacted forests across a range of forest types and conditions.

\section{ACKNOWLEDGments}

This research was supported by a grant from the National Science Foundation (DEB-0075236) and the Lydia P. Anderson Fellowship, the Wood-Rill Fellowship from the University of Minnesota Center for Hardwood Ecology, and a University of Minnesota Doctoral Dissertation Fellowship. The useful comments of several anonymous reviewers helped to improve the manuscript.

\section{Literature Cited}

Aaseng, N. E., J. C. Almendinger, R. P. Dana, B. C. Delaney, H. L. Dunevitz, K. A. Rusterholz, N. P. Sather, and D. S. Wovcha. 1993. Minnesota's native vegetation: a key to natural communities. Version 1.5. State of Minnesota, Department of Natural Resources, Section of Wildlife, St. Paul, Minnesota, USA.

Aber, J. D., J. M. Melillo, and C. A. McClaugherty. 1990. Predicting long-term patterns of mass loss, nitrogen dynamics, and soil organic matter formation from initial fine litter chemistry in temperate forest ecosystems. Canadian Journal of Botany 68:2201-2208.

Alban, D. H., and E. C. Berry. 1994. Effects of earthworm invasion on morphology, carbon, and nitrogen of a forest soil. Applied Soil Ecology 1:243-249.

Arrhenius, O. 1921. Species and area. Journal of Ecology 9:9599.

Augustine, D. J., L. E. Frelich, and P. A. Jordon. 1998. Evidence for two alternate stable states in an ungulate grazing system. Ecological Applications 8:1260-1269.

Baskin, C. C., and J. M. Baskin. 1998. Seeds: ecology, biogeography, and evolution of dormancy and germination. Academic Press, San Diego, California, USA.

Bever, J. D., K. M. Westover, and J. Antonovics. 1997. Incorporating the soil community into plant population dynamics: the utility of the feedback approach. Journal of Ecology 85:561-573.

Black, O. F. 1918. Calcium oxalate in the Dasheen. American Journal of Botany 5:447-451.

Bohlen, P. J., P. M. Groffman, T. J. Fahey, M. C. Fisk, E. R. Suarez, D. M. Pelletier, and R. T. Fahey. 2004a. Ecosystem consequences of exotic earthworm invasion of north temperate forests. Ecosystems 7:1-12.

Bohlen, P. J., D. M. Pelletier, P. M. Groffman, T. J. Fahey, and M. C. Fisk. 2004b. Influence of earthworm invasion on redistribution and retention of soil carbon and nitrogen in north temperate forests. Ecosystems 7:13-27.

Bormann, F. H., and G. E. Likens. 1979. Pattern and process in a forested ecosystem. Springer-Verlag, New York, New York, USA.

Bouché, M. B. 1977. Strategies lombriciennes. Pages 122-132 in U. Lohm and T. Persson, editors. Soil organisms as components of ecosystems: proceedings of the VI International Soil Zoology Colloquium of the International Society of Soil Science (ISSS), Uppsala, Sweden, 21-25 June 1976. Swedish Natural Science Research Council, Stockholm, Sweden. 
Brown, V. K., and A. C. Gange. 1989. Herbivory by soildwelling insects depresses plant species richness. Functional Ecology 3:667-671.

Brundrett, M. C., and B. Kendrick. 1988. The mycorrhizal status, root anatomy, and phenology of plants in a sugar maple forest. Canadian Journal of Botany 66:1153-1173.

Callaham, M. A., Jr., G. González, C. M. Hale, L. Heneghan, S. L. Lachnicht, and X. Zou. In press. Policy and management responses to earthworm invasions. Biological Invasions.

Calvey, E. M., K. D. White, J. E. Matusik, D. Y. Sha, and E. Block. 1998. Allium chemistry: identification of organosulfur compounds in ramp (Allium tricoccum) homogenates. Phytochemistry 49:359-364.

Devliegher, W., and W. Verstraete. 1997. Microorganisms and soil physico-chemical conditions in the drilosphere of Lumbricus terrestris. Soil Biology and Biochemistry 29: 1721-1729.

Dugravot, S., E. Thibout, A. Abo-Ghalia, and J. Huignard. 2004. How a specialist and a non-specialist insect cope with dimethyl disulfide produced by Allium porrum. Entomologia Experimentalis et Applicata 113:173-179.

Dymond, P., S. Scheu, and D. Parkinson. 1997. Density and distribution of Dendrobaena octaedra (Lumbricidae) in aspen and pine forests in the Canadian Rocky Mountains (Alberta). Soil Biology and Biochemistry 29:265-273.

Edwards, C. A., P. J. Bohlen, D. R. Linden, and S. Subler. 1995. Earthworms in agroecosystems. Pages 185-214 in P. F. Hendrix, editor. Earthworm ecology and biogeography in North America. Lewis, Boca Raton, Florida, USA.

Francis, R., and D. J. Read. 1994. The contributions of mycorrhizal fungi to the determination of plant community structure. Plant and Soil 159:11-25.

Gates, G. E. 1982. Farewell to North American megadriles. Megadrilogica 4:77.

Grime, J. P. 1979. Plant strategies and vegetation processes. John Wiley and Sons, Chichester, UK.

Groffman, P. M., P. J. Bohlen, M. C. Fisk, and T. J. Fahey. 2004. Exotic earthworm invasion and microbial biomass in temperate forest soils. Ecosystems 7:45-54.

Gundale, M. J. 2002. The influence of exotic earthworms on soil organic horizon and the rare fern Botrychium mormo. Conservation Biology 16:1555-1573.

Hale, C. M. 2004. Ecological consequences of exotic invaders: interactions involving European earthworms and native plant communities in hardwood forests. Dissertation. University of Minnesota, Department of Forest Resources, St. Paul, Minnesota, USA.

Hale, C. M., L. E. Frelich, and P. B. Reich. 2004. Allometric equations for estimation of ash-free dry mass from length measurements for selected European earthworm species (Lumbricidae) in the western Great Lakes region. American Midland Naturalist 151:179-185.

Hale, C. M., L. E. Frelich, and P. B. Reich. 2005a. Exotic European earthworm invasion dynamics in northern hardwood forests of Minnesota, USA. Ecological Applications 15:848-860.

Hale, C. M., L. E. Frelich, P. B. Reich, and J. Pastor. $2005 b$. Effects of European earthworm invasion on soil characteristics in northern hardwood forests of Minnesota, U.S.A. Ecosystems 8:911-927.

Hendriksen, N. B. 1990. Leaf litter selection by detrivore and geophagous earthworms. Biology and Fertility of Soils 10: $17-21$.

Hendrix, P. F., M. A. Callaham, S. L. Lachnicht, J. M. Blair, S. W. James, and X. Zou. 1999. Stable isotopic studies of resource utilization by nearctic earthworms (Diplocardia, Oligochaeta) in subtropical savanna and forest ecosystems. Pedobiologia 43:818-823.

Holdsworth, A. R., L. E. Frelich, and P. B. Reich. 2004. Landscape patterns of earthworm invasion and plant composition in northern temperate hardwood forests. XIVth International Colloquium on Soil Zoology and Ecology. Mont Saint Aignan, France, 30 August-3 September 2004. The Université de Rouen, Mont Saint Aignan, France.

Host, G. E., and K. S. Pregitzer. 1991. Ecological species groups for upland forest ecosystems of northwestern Lower Michigan. Forest Ecology and Management 43:87-102.

James, S. W. 1995. Systematics, biogeography, and ecology of Nearctic earthworms from eastern, central, southern, and southwestern United States. Pages 29-52 in P. F. Hendrix, editor. Earthworm ecology and biogeography in North America. Lewis, Boca Raton, Florida, USA.

James, S. W., and M. R. Cunningham. 1989. Feeding ecology of some earthworms in Kansas tallgrass prairie. American Midland Naturalist 121:78-83.

Johnson, N. C., D. G. Tilman, and D. Wedin. 1992. Plant and soil controls on mycorrhizal fungal communities. Ecology 73: 2034-2042.

Kostel-Hughes, F. 1995. The role of soil seed banks and leaf litter in the regeneration of native and exotic tree species in urban forests. Dissertation. Fordham University, Bronx, New York, USA.

Kotar, J., J. A. Kovach, and T. L. Burger. 2002. A guide to forest communities and habitat types of northern Wisconsin. Second edition. Department of Forest Ecology and Management, University of Wisconsin-Madison, Madison, Wisconsin, USA.

Lavelle, P. 1997. Faunal activities and soil processes: adaptive strategies that determine ecosystem function. Pages 93-122 in M. Begon and A. H. Fitter, editors. Advances in ecological research. Academic Press, San Diego, California, USA.

Lawrence, B., M. C. Fisk, T. J. Fahey, and E. R. Suárez. 2001. Influence of nonnative earthworms on mycorrhizal colonization of sugar maple (Acer saccharum). New Phytologist 157: 145-153.

Leck, M. 1989. Ecology of soil seed banks. Academic Press, San Diego, California, USA.

Magurran, A. E. 1988. Ecological diversity and its measurement. Princeton University Press, Princeton, New Jersey, USA.

McClaugherty, C. A., J. Pastor, J. D. Aber, and J. M. Melillo. 1985. Forest litter decomposition in relation to soil nitrogen dynamics and litter quality. Ecology 66:266-275.

McCune, B., and J. B. Grace. 2002. Analysis of ecological communities. MjM Software Design, Gleneden Beach, Oregon, USA.

McCune, B., and M. J. Mefford. 1999. PC-ORD for windows: multivariate analysis of ecological data. Version 4.25. MjM Software Design, Gleneden Beach, Oregon, USA.

McLean, M. A., and D. Parkinson. 1997. Changes in structure, organic matter, and microbial activity in pine forest soil following the introduction of Dendrobaena octaedra (Oligochaeta, Lumbricidae). Soil Biology and Biochemistry 29:537540 .

Mielke, P. W., and K. J. Berry. 2001. Permutation methods: a distance function approach. Springer Series in Statistics. Springer-Verlag, New York, New York, USA.

Newman, E. I., and P. Reddell. 1988. Relationship between mycorrhizal infection and diversity in vegetation: evidence from the Great Smokey Mountains. Functional Ecology 2: 259-262.

Nielsen, G. A., and F. D. Hole. 1963. A study of the natural processes of incorporation of organic matter into soil in the University of Wisconsin Arboretum. Wisconsin Academy of Sciences, Arts, and Letters 52:213-227.

Pastor, J., Y. Cohen, and R. Moen. 1999. Generation of spatial patterns in boreal forest landscapes. Ecosystems 2:439-450.

Pastor, J., A. Downing, and H. E. Erickson. 1996. Species-area curves and diversity-productivity relationships in beaver meadows of Voyageurs National Park, Minnesota, USA. Oikos 77:399-406. 
Ponge, J. F., J. Andre, O. Zackrisson, N. Bernier, M. C. Nilsson, and C. Gallet. 1998. The forest regeneration puzzle: biological mechanisms in humus layer and forest vegetation dynamics. BioScience 48:523-530.

Proulx, N. 2003. Ecological risk assessment of non-indigenous earthworm species. Minnesota Department of Natural Resources, St. Paul, Minnesota, USA.

Reynolds, J. W., D. R. Linden, and C. M. Hale. 2002. The earthworms of Minnesota (Oligochaeta: Acanthodrilidae, Lumbricidae and Megascolecidae). Megadrilogica 8:85-100.

Rozen, A. 1988. The annual cycle in populations of earthworms (Lumbricidae, Oligochaeta) in three types of oak-hornbeam of the Niepolomicka Forest. II. Dynamics of population numbers, biomass and age structure. Pedobiologia 31:169178.

SAS Institute. 2001. JMP. Version 4.0.5. SAS Institute, Cary, North Carolina, USA.

Scheu, S., and D. Parkinson. 1994. Effects of earthworms on nutrient dynamics, carbon turnover, and microorganisms in soils from cool temperate forests of the Canadian Rocky Mountains - laboratory studies. Applied Soil Ecology 1:113125.

Shannon, C. E., and W. Weaver. 1964. The mathematical theory of communication. University of Illinois Press, Urbana, Illinois, USA.

Springett, J. A. 1983. Effect of five species of earthworms on soil properties. Journal of Applied Ecology 20:865-872.

Suárez, E. R., D. M. Pelletier, T. J. Fahey, P. M. Groffman, P. J. Bohlen, and M. C. Fisk. 2004. Effects of exotic earthworms on soil phosphorus cycling in two broadleaf temperate forests. Ecosystems 7:28-44.
Tomlin, A. D., M. J. Shipitalo, W. M. Edwards, and R. Protz. 1995. Earthworms and their influence on soil structure and infiltration. Pages 159-184 in P. F. Hendrix, editor. Earthworm ecology and biogeography in North America. CRC Press, Boca Raton, Florida, USA.

USDA. 1997. Soil survey of Cass County, Minnesota. National Cooperative Soil Survey, U.S. Department of Agriculture and Minnesota Natural Resources Conservation Service and Forest Service, St. Paul, Minnesota, USA.

van der Heijden, M. G. A., T. Boller, A. Wiemken, and I. R. Sanders. 1998. Different arbuscular mycorrhizal fungal species are potential determinants of plant community structure. Ecology 79:2082-2091.

Vitousek, P. M. 1986. Biological invasions and ecosystem properties: Can species make a difference? Pages 163-176 in H. A. Mooney and D. R. Drake, editors. Ecology of biological invasions of North America and Hawaii. Springer-Verlag, New York, New York, USA.

Vitousek, P. M. 1990. Biological invasions and ecosystem processes: towards an integration of population biology and ecosystem studies. Oikos 57:7-13.

Watkinson, A. R. 1998. The role of the soil community in plant population dynamics. Trends in Ecology and Evolution 13: 171-172.

Whittaker, R. H. 1972. Evolution and measurement of species diversity. Taxon 21:213-251.

Woodcock, E. F. 1925. Observations on the poisonous plants of Michigan. American Journal of Botany 12:116-131.

Zaborski, E. R. 2003. Allyl isothiocyanate: an alternative chemical expellant for sampling earthworms. Applied Soil Ecology 22:87-95.

\section{APPENDIX A}

A table showing correlation coefficients of herbaceous-plant species total cover with ordination axis and the number of plots within which each was found (Ecological Archives E087-095-A1).

\section{APPENDIX B}

A figure showing overlays of sample plots on the herbaceous-plant species ordination (Ecological Archives E087-095-A2). 